\title{
Malignant Lymphoma Mimicking Retroperitoneal Fibrosis
}

\author{
Yoichi Hoshino $^{1}$, Isao Yamada ${ }^{2}$ and Shun-ichi Shimano ${ }^{1}$
}

Key words: malignant lymphoma, sclerosing variant of follicular lymphoma, retroperitoneal fibrosis

(Intern Med Advance Publication)

(DOI: 10.2169/internalmedicine.7142-21)
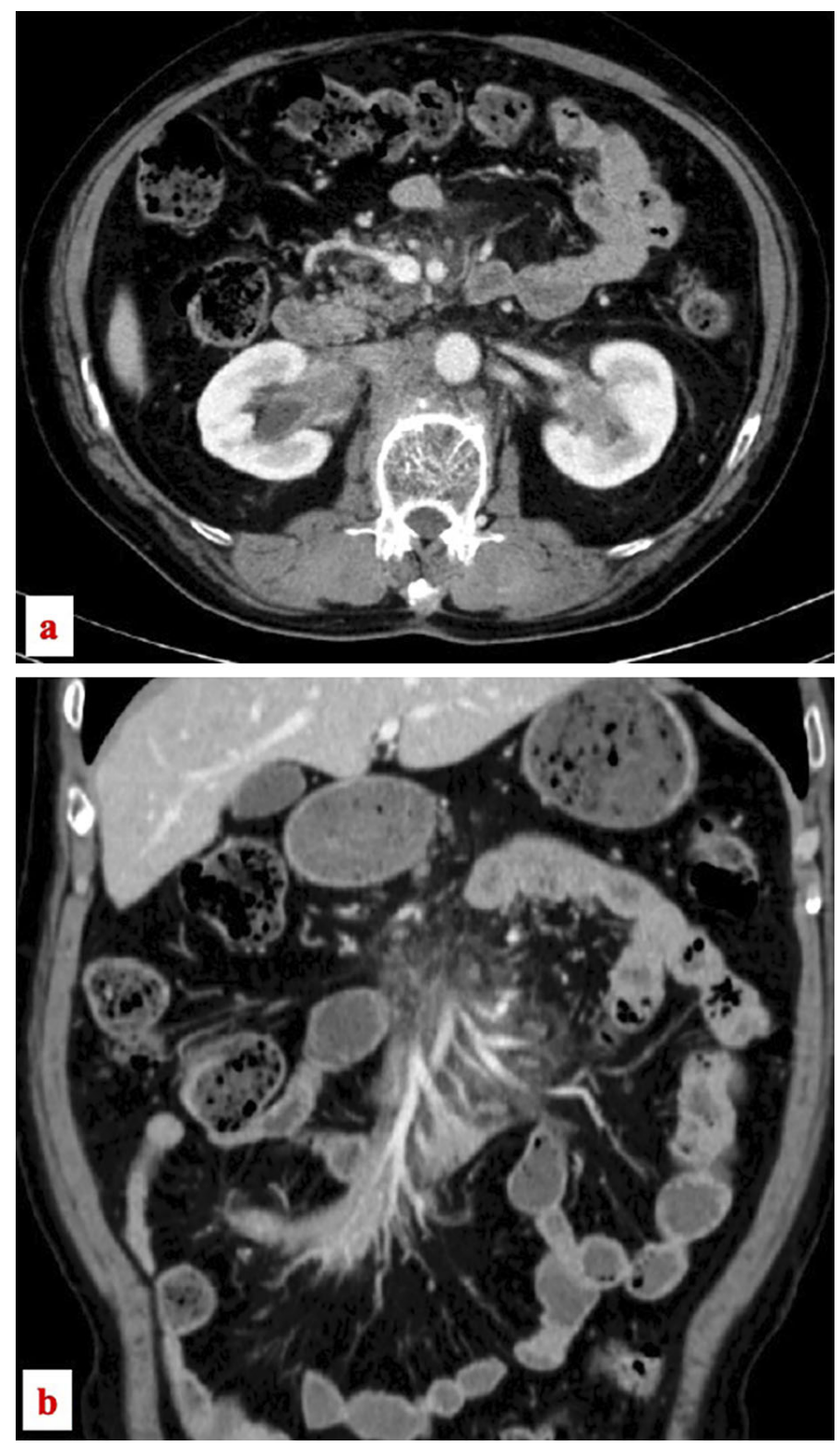

Picture 1.

${ }^{1}$ Department of Internal Medicine, Keiaido Hospital, Japan and ${ }^{2}$ Department of Surgery, Keiaido Hospital, Japan Received: January 22, 2021; Accepted: March 7, 2021; Advance Publication by J-STAGE: April 19, 2021 Correspondence to Dr. Yoichi Hoshino, fwgi9866@nifty.com 

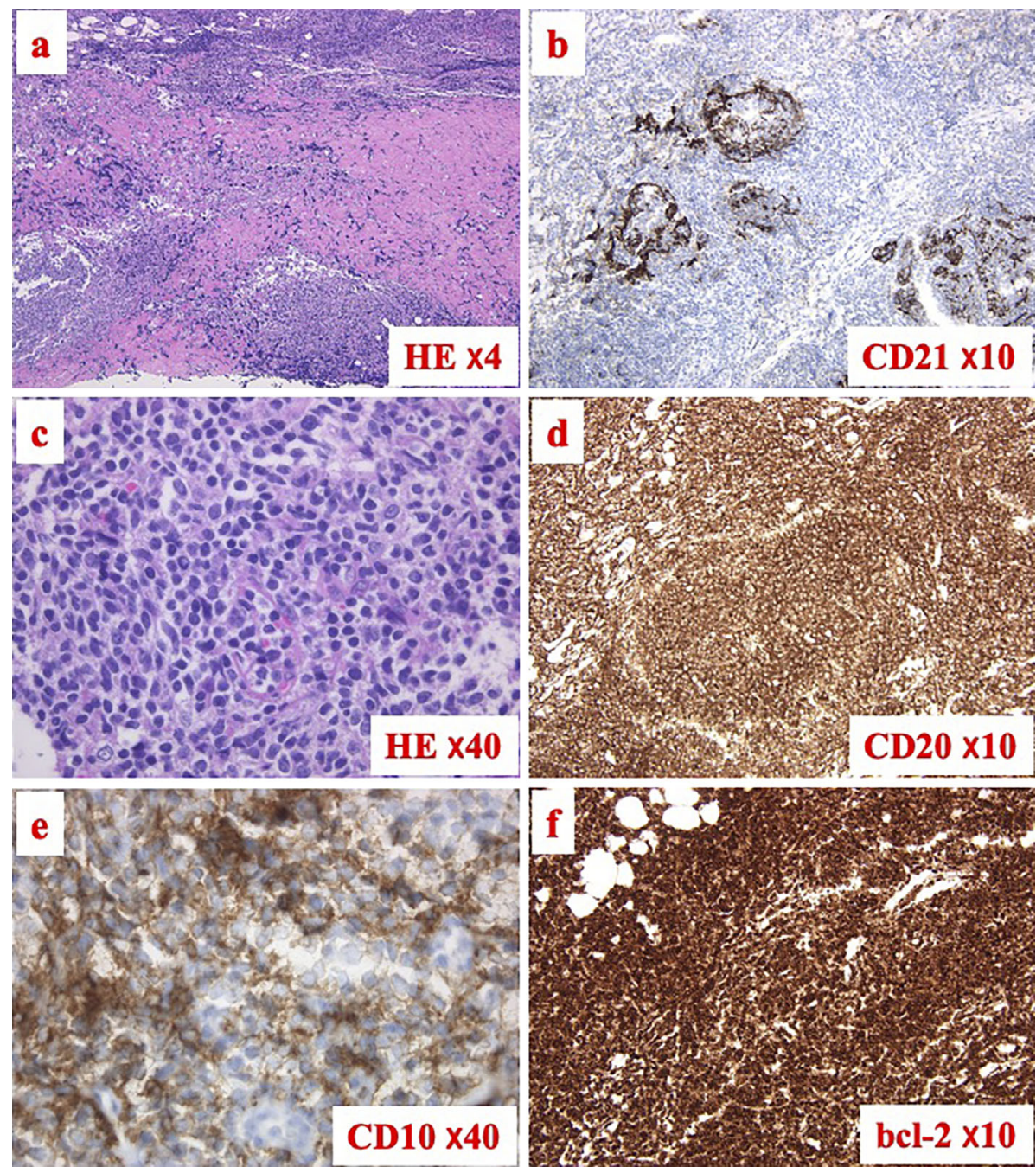

Picture 2.

A 69-year-old man presented with a complaint of abdominal discomfort. The findings of computed tomography mimicked the features of retroperitoneal fibrosis: a soft tissue mass surrounding the inferior vena cava, bilateral renal pelvises and mesenterium with no evidence of lymphadenopathy (Picture A-a and b). Although the serum levels of $\mathrm{LDH}$ and IgG4 were normal, the serum soluble interleukin-2 receptor level was elevated $(1,580 \mathrm{U} / \mathrm{mL})$. A histopathological examination of the resected mesenteric specimens revealed chronic inflammation with prominent fibrosis (Picture B-a), preserved lymphoid follicles with reticular formation of $\mathrm{CD} 21^{+}$follicular dendric cells (Picture B-b), and no evidence of obliterative phlebitis. An examination under highpower magnification showed the proliferation of $\mathrm{CD}_{2} 0^{+}$, $\mathrm{CD}_{10} 0^{+}$and bcl- $2^{+}$medium-sized atypical lymphocytes (Picture B-c to f). The patient was diagnosed with the sclerosing variant of grade 1 follicular lymphoma (FL) without bone marrow infiltration and showed complete remission following chemotherapy. The sclerosing variant of FL accounts for $74 \%$ of retroperitoneal non-Hodgkin lymphoma cases (1).
However, malignant lymphoma presenting as retroperitoneal fibrosis in the absence of lymphadenopathy is rare (2).

The authors state that they have no Conflict of Interest (COI).

\section{Acknowledgement}

The authors are grateful to the late Masaru Kojima for confirming the histopathological diagnosis.

\section{References}

1. Waldron JA, Newcomer LN, Katz ME, Cadman E. Sclerosing variants of follicular center cell lymphomas presenting in the retroperitoneum. Cancer 52: 712-720, 1983.

2. Hatsuse M, Fuchida S, Okano A, Murakami S, Haruyama H, Shimazaki C. Primary retroperitoneal diffuse large B cell lymphoma with sclerosis mimicking retroperitoneal fibrosis. Rinsho Ketsueki 53: 2018-2020, 2012 (in Japanese, Abstract in English).

The Internal Medicine is an Open Access journal distributed under the Creative Commons Attribution-NonCommercial-NoDerivatives 4.0 International License. To view the details of this license, please visit (https://creativecommons.org/licenses/ by-nc-nd/4.0/).

(C) The Japanese Society of Internal Medicine Intern Med Advance Publication 